\title{
Reorientation of livestock research in Poland
}

\author{
E.R. Ørskov \\ Rowett Research Institute, Bucksburn, Aberdeen AB2 9SB, U.K.
}

(Received 24 October 1991; accepted 29 November 1991)

INTRODUCTION

I have been asked to write a short article for the first issue of this Journal. I consider this an honour and, instead of writing about livestock experiments as I usually do, I have decided to use the opportunity to tell you how I, as an outsider, have viewed livestock research in Poland and, perhaps more importantly, to discuss what I think are the important issues for research policy in a free Poland. While I have visited Poland on several occasions I do, of course, admit that I certainly do not know all the answers, but perhaps my experience in Poland an in many other countries can provide some food for thought and debate to assist in successful livestock development in Poland. If it helps to create debate about these issues I shall feel greatly rewarded.

\section{IMPRESSIONS OF POLISH LIVESTOCK RESEARCH}

I have learned from statistics, and indeed from farm visits, that $85 \%$ of Polish farms are on private land with an average size of about 6 ha and that the number of small farms increased during the period of 1950-1970 to avoid collectivisation. Consequently I was somewhat surprised to find that all the research problems were identified from the point of view of large state and collective farms; the problems studied bore no relationship to problems found on the small farm. No doubt the prevailing political system found some difficulty in promoting research which directly supported small private farms.

\section{TECHNOLOGY LED}

Besides the orientation of research towards large farms, there was also the problem of technology led research. Thus technologies developed in the West were uncritically adopted, even though their relevance to Polish agriculture was

(C) Institute of Animal Physiology and Nutrition 
questionable. I refer here to such technologies as AI, embryo transfer, and the introduction of high yielding cows that needed concentrate feeding, even though Poland at that time was importing grain. The general attitude to dairy cows seemed to be, as in the USA, that high yields meant success, regardless of the feed resources used to achieve these yields. No effort seems to have been made to match the potential of the animals to prevailling resources.

\section{EXTENSION SERVICES}

It appears that the extension services, like research work, were mainly geared to give advice to large state farms. I once asked a small Polish farmer whether he received advice from extension services. His blunt answer was no and that had he listened to them he would have been dead! No doubt this was an exaggerated opinion, but I believe it reflects a deep distrust by small farmers which needs to be overcome. sholrovil stio ti britiucuod ne zi

\section{REORIENTATION OF RESEARCH AND EXTENSION}

There is no doubt, and I believe there is a general agreement, that the research and extension services now have to be reoriented towards the small farmer, for small farmers are a great resource that Poland can now exploit to the full. I have often been told that small farms are uneconomical and a hindrance to agricultural development. I believe that Poland is fortunate in having its small farm sector intact and has a rural population that considers farming as a way of life. Compare the situation with neighbouring countries which were virtually all collectivised. I have also been told the Polish farmer is deeply bonded to his land, for ceriainly it is very difficult to make him sell his land in order to create larger, more economical farms. Here, however, my experience with small farmers in many parts of the world can assist because there are some characteristics which are common to subsistence farmers and the Polish small holder.

MINIMISING RISK

First of all one of the overriding factors in decision making by small farmers world wide is to minimise risk or in other words to secure their livelihood; this means that opportunities for greater gains but at higher risk are rejected. One can only afford to take risks in proportion to the reserves of money or resources that will allow one to survive failure, and small farmers are usually poor. Subsistence farmers who are owners of land will never sell the land unless it can be exchanged for another way of making a living that is perceived to be equally or more secure. To take land away from them is like pulling out the rug on which they stand. In this respect Polish farmers are no different from subsistence farmers in other 
parts of the world. The political upheaval that has been affecting Poland will have further strengthened the need for the feeling of security that the ownership of land provides.

\section{RESPONSE TO INTERVENTION}

It has often been said that subsistence farmers are traditionally ignorant and unwilling to change. If their need for security is recognised it is my experience that subsistence farmers respond rapidly to sound developments, but it is important that the constraints are indentified and removed in the correct order. This in fact is not different from any other business where, before further investment, it is necessary to remove the bottlenecks in the right order. In both cases advisers from outside may have difficulty in identifying the constraints.

\section{FARM SIZE}

While many Polish farms may be too small to make economical units there are some complex issues which have to be addressed by long-term planners of Polish agriculture. First of all there is a desire to maintain the rural population until urban industries can provide efficient employment. To enlarge the farms so that they are economical units of say 30 to 40 ha will at a stroke more than halve the rural population. Presently a large proportion of small farmers have other sources of income; apparently only about $20 \%$ of them derive their income exclusively from farming. Is this desirable or should full-time farmers be encouraged? These are questions only Poles can and should answer. No doubt there is room for rationalisation of land so that each farm is united in one rather than many pieces. I, for one, would prefer small mixed crop-livestock farms as I believe they are the most sustainable and Poland, because of its small farm sector, could provide a model for such development. Mixed farms can make much better use of renewable resources such as feedstuffs from crop residues than large specialised farms. In the West disposal of crop residues cause pollution problems in specialised crop farms, and disposal of excreta cause pollution problems in specialised livestock farms. For the small mixed farm both crop residues and excreta are valuable resources.

It has been shown that productivity per unit of land is not consistently lower with part-time farmers than full-time farmers. Part-time farmers can afford to make rational use of machinery which can be accomplished by hiring contractors or by a small farmer investing in one implement and hiring his services to others.

You may well ask why, in an article dealing with livestock research, do I touch on issues like farm size and part-time or full-time farmers, small or large, mixed or specialised. I do this deliberately because, unless there is a vision as to which direction Polish agriculture is going, it will not be possible to adequately 
identify the problems and opportunities that lie in the future and call for research.

If the goal is mixed small farms run to a large extent by part-time farmers then there are certain issues relating to livestock which need attention.

\section{WHICH TYPE OF ANIMAL IS MOST SUITABLE FOR MILK PRODUCTION?}

The present emphasis on very high milk yields necessitating the feeding of concentrate is probably wrong for part-time farmers. He needs cows that are easy to manage. He needs feeds that are easy and safe to feed. He would probably prefer to milk once a day rather than 2 or 3 times a day. Such a system could perhaps be combined with partial suckling of calves to produce high quality calves for beef production. Part-time farmers need some high quality feeds that can be fed, perhaps once daily without causing problems of acidosis and ketosis.

\section{PRODUCTS}

It is quite clear that Poland can produce livestock products well in excess of home consumption even without luxurious use of fertilisers. If products are intended for export then there must be a vigorous drive to produce high quality products. The emphasis must be on quality and not quantity. At present there is emphasis on so-called organically produced products in the EEC. Polish farmers could produce these with very little change in the system. If this is to be pursued then certification and control of origin will be essential together with very high quality standards.

Small farmers need to be organised and to control their own organisation, as by the development of co-operative marketing, and through this maintain the discipline of standards.

\section{EXTENSION SERVICES}

In order to overcome any distrust of extension services that small farmers may have inherited the emphasis in the education of extension workers needs to be changed away from large farms to small farms. Apart from that most successful extension services have a responsibility to farmer organisations. Farmers' organisations must play a part in the hiring and firing of extension workers. However, they also need to contribute to their costs. There is no doubt that confidence or trust needs to be restored. If the small mixed farms are to be retained then what is needed is the expert specialising in farm systems rather than only those specialising in plants and animals. Changes in one part of the farm system will inevitably cause changes in other parts of the system such as resource use, labour use, etc. 
Poland has a unique opportunity to develop its agriculture and livestock industries, avoiding the many mistakes caused by large specialised farms in the West and state farms in the East. From an environmental point of view mixed crop-livestock farms have stood the test of time. They are sustainable. They are labour intensive and support a large rural population. It is a great challenge to planners, in consultation with farmers, to set out a path for Polish agriculture, for livestock and for livestock products. When this is agreed upon the livestock research can play an important role in helping to remove problems and develop the opportunities in such development. It will no doubt lead to painful termination of some research activities but challenging new work will emerge with the reorientation to small farm problems. It will also allow teaching institutions to reorientate their courses so as to produce the right servants to assist in such development. 